\title{
Replacement of Artemia franciscana Nauplii by Microencapsulated Diets: Effect on Development, Digestive Enzymes, and Body Composition of White Shrimp, Litopenaeus vannamei, Larvae
}

\author{
Pedro Gallardo ${ }^{1, *}$, Gemma Martínez ${ }^{1}$, Gabriela Palomino ${ }^{1}$, Adriana Paredes ${ }^{1}$, Gabriela Gaxiola ${ }^{1}$, \\ Gerard Cuzon ${ }^{2}$, Ruth Pedroza-Islas ${ }^{3}$
}

\author{
${ }^{1}$ Unidad Multidisciplinaria de Docencia e Investigación, Facultad de Ciencias, UNAM, Sisal, Yucatán, Mexico \\ ${ }^{2}$ Centre Océanologique du Pacifique (COP), IFREMER, BP 7004, Taravao, Tahiti, Polynesie Francaise \\ ${ }^{3}$ Departamento Ingenieríay Ciencias Químicas, Universidad Iberoamericana, Ciudad de Mexico, Mexico \\ *: Corresponding author : Pedro Gallardo, tel (52) 9889120020 ; fax (52) 9889120149 ; \\ email address : pedrogallardo2@gmail.com
}

\begin{abstract}
:
The effects of two microencapsulated feeds were evaluated on development, growth, survival, proteolytic activity, and biochemical composition of white shrimp, Litopenaeus vannamei, larvae. The treatments were: (1) basal microcapsules (BM), (2) microcapsules containing krill hydrolysate (BMK), and (3) live food control (LFC: Artemia franciscana nauplii) with all treatments receiving algae (Chaetoceros ceratosporum and Tetraselmis chuii). No significant differences were found in development index and survival among larvae. Growth rate was significantly higher in larvae fed LFC $(15 \pm 0.06 \% / d)$ as compared with those offered the BM diet $(7.5 \pm 0.5 \% / d)$ with the BMK $(11 \pm 0.04 \% / d)$ treatment producing intermediate results. The activity of total proteases and chymotrypsin decreased significantly after Mysis I (MI) in larvae fed LFC or BMK. Protein content of larvae increased significantly toward PL1. The acylglycerides content in MIII fed on LFC $(2.3 \pm 0.2 \% / \mathrm{dw})$ was higher than that $\mathrm{Ml}$ fed BM $(1 \pm 0.01 \% / \mathrm{dw})$. No difference was observed in the cholesterol $(\mathrm{CH})$ content of the larvae. The acylglycerides/protein and cholesterol/protein ratios showed a decreasing pattern between $\mathrm{MI}$ and PL1, indicating that these two ratios were related to ontogenetic shifts. These results demonstrate improvements in microparticulate diets when krill hydrolysates are included in the formulation.
\end{abstract}


The substitution of live food with artificial diets in crustacean larvae has been associated with reduced digestibility, hindering nutritional assimilation (Kumlu and Jones 1997). Recent research has demonstrated the efficiency of microparticulate and microencapsulated diets when used as partial substitute of live feed, obtaining survival and development rates similar to those obtained with live food, albeit, sometimes with lower growth or survival (Gallardo et al., 2002; Pedroza et al., 2004; Sarvi et al, 2010)., More recent trials have indicated that when high quality inter feeds are utilized some live foods may be replaced with artificial feeds (Cuzon, pers. comm.).

Protein hydrolysates have been considered as stimulators of enzymatic activity in fish and crustacean larvae (Cahu and Zambonino 1994, 1997; Carvahlo et_al. 1998; Cahu et al. 1999; Ravallec-Plé, 2000). Reduction in developmental time and increases in survival have been reported in larvae of carp (Carvahlo et al. 1998) and seabass (Cahu et al. 1999) when protein hydrolysates were included in the diet. The presence of protein hydrolysates in larval shrimp feeds has resulted in shifts in digestive enzymes. (Ravallec-Plé, 2000) which may result in improved of digestive performance and in growth and larvae survival.

Endogenous secretory peptides, such as gastrin and cholecystokinin (CKK), have been identified in the gastric tract of many crustacean species (Reifel et al., 1983; Aldman et al. 1989; Reinecke et al. 1992; Van Wormhoudt and Dircksen 1990). Gastrin and CKK depict a large spectrum of activities, including stimulation of protein synthesis (Johnson et al., 1978), control of intestinal peristalsis, and secretion of digestive enzymes (Ravallec-Plé 2000). Ravallec-Plé (2000) reported the presence of these peptides in fish and shrimp hydrolysates produced by enzyme controlled hydrolysis using the alkalase (enzyme of bacterial origin) as control, and purified enzymes obtained from the hepatopancreas of $\underline{L}$. vannamei juveniles. An enzymatic activity inductor at different larval stages was determined in larvae of the shrimp $\underline{L}$. vannamei, and it was concluded that it could be used as an indicator to test the secretory effect of peptides included in protein hydrolysates of marine origin (Ravallec-Plé, 2000). Also krill hydrolysate can contain secretory peptides that might induce digestive enzyme activity in mysis of $\underline{L}$. vannamei when they are included in the artificial feed. The krill hydrolysate is made by partial enzymatic hydrolysis under controlled digestive conditions; it contains high levels of short chain polypeptides (in two populations: one corresponding to peptides of less than $14.4 \mathrm{kDa}$ and the other to peptides bigger than 66 kDa) (Córdova-Murueta and García-Carreño 2002). Its use as an ingredient in aquaculture feed has been investigated (Kolkowski et al., 2000; Storebakken, 1988; Nicol and Endo, 1997). This research was designed to analyze the influence of krill hydrolysate (Euphausia superba) included in a microencapsulated diet (Gallardo et al. 2002) as a substitute of $\underline{A}$. franciscana nauplii in the feeding of $\underline{L}$. vannamei larvae. Special focus was placed on characterizing the enzymatic activity of proteinases, variations of the body chemical composition (total soluble protein, acylglycerides and cholesterol) at different larval stages, as well as effects on growth, development index and survival rate.

\section{Materials and Methods}

Litopenaeus vannamei larvae in the nauplii III-IV sub-stage was obtained from the shrimp farm of Industrias Pecis, S.A. de C.V., located in Sisal, Yucatán, Mexico. Animals were transported to the laboratory, where they were acclimated to seawater temperature $\left(28 \pm 0.5^{\circ} \mathrm{C}\right)$. 


\subsection{Experimental Design and Diet Composition}

A complete randomized design with 3 feeding treatments and 3 replicates per treatment was used. The krill hydrolysate was included replacing squid meal in a previous formulation tested in microparticles reported by Gallardo et al (2002). Both diets (BM and BMK) were produced according to the procedures reported by Pedroza et al $(1999,2000)$. The shrimp larvae formulation was added to the polysaccharide blend in aqueous solution obtaining dispersion with $25 \%$ solids content before spray drying. The proportion of agent's encapsulants: diet was 2: 1 to maintain power encapsulant of diet and according to the procedure established by Pedroza et al (2000). Table 1 presents the formulation and chemical composition of diets microencapsulated.

The aqueous dispersion was dried in a mobile minor niro atomizer (Niro, Copenhagen, Denmark) spray dryer, equipped with a rotary centrifugal atomizer (Niro, Copenhagen, Denmark). The dispersion was fed to the spray dryer at a rate of $20 \mathrm{ml} / \mathrm{min}$, a 2-bar air pressure, an inlet air temperature of $170 \pm 5^{\circ} \mathrm{C}$, and an outlet temperature of $110 \pm 5^{\circ}$ C.

The mean volumetric particle size of the microcapsules was determined according to Pedroza et al. (2000) with a Malvern droplet and particle size analyzer series 2600 (Malvern Instruments, Malvern, Worcs., UK). The mean particle size of basal microcapsules was $12 \mu \mathrm{m}$ (range of 1-42 $\mu \mathrm{m}$ ) and that of microcapsules with krill hydrolysate was $9 \mu \mathrm{m}$ (range of 1-36 $\mu \mathrm{m}$ ). The feeding frequency of the formulated diet was every 4 hours $(0: 00,4: 00,8: 00,12: 00,16: 00$, and 20:00 hours) considering the degree of hydration maxima and leaching of microcapsules for their stay in seawater according to Pedroza et al. (2000).

Live food control (LFC) consisted of microalgae ( $\underline{\mathrm{C}}$. ceratosporum and $\underline{\mathrm{T}}$. chuii) and $\underline{\mathrm{A}}$. franciscana nauplii according feeding schedule for Treece and Yates (1990) and were adjusted daily every 12 hours (8:00 and 20:00 hours) according to Gallardo et al. (2002). The microalgae were used in the same density and frequency in treatments with BM and BMK.

\subsection{Experimental Condition}

To evaluate development and growth groups of 400 larvae (protozoea III; PZ III) per tank were placed in white conical-bottom tanks made of fiberglass in $8 \mathrm{~L}$ of seawater, with constant aeration. To evaluate survival rates groups of larvae (50 $\mathrm{PZ}$ III) per flask were placed in round bottom 1-L glass flasks. Each treatment was replicated three times for both culture systems. Additionally, 4000 larvae were placed in 100-L tanks and were sampled in three groups (50 organisms each one) by larval sub-stage to evaluate digestive enzymatic activity, total protein, acylglycerides, and cholesterol content.

Seawater was filtered through sand filter, cartridges of 20,5 , and $1 \mu \mathrm{m}$ and then passed through ultraviolet light and re-circulated for 3 hours in a biological filter (FLUVAL, Mod. 403, HAGEN, U.S.A) to eliminate suspended organic material and to control bacteria populations. The physicochemical conditions during the experiment were: average temperature $28.5 \pm 1^{\circ} \mathrm{C}$, salinity of $35 \pm 1 \mathrm{~g} / \mathrm{l}$, dissolved oxygen of $5.7 \pm 0.7 \mathrm{mgO}_{2} / \mathrm{L}$ and $\mathrm{pH}$ of $8.1 \pm 0 . \overline{2}$. The experiment began from $P Z_{\text {III }}$ up to $P L_{1}$. 


\subsection{Specific Growth Rate (SGR), Development Index (DI) and Survival}

Growth and DI were evaluated in 15 larvae from each treatment ( 5 larvae by tank) each day. For the wet weight, the organisms were placed in a microbalance, CAHN-33 (Orion Inc., Beverly, MA, USA), with a $0.0001 \mathrm{mg}$ accuracy. From weight data given in micrograms $(\mu \mathrm{g})$, a specific growth rate $(S G R=[((\operatorname{lnWf}-\operatorname{InWi}) / \mathrm{t})$ * 100]) was calculated, considering $\mathrm{PL}_{1}$ (final) and $P Z_{\text {III }}$ (initial) according to Gallardo et al. $(1995,2002$ ) and Pedroza et al. (2004). The DI was assessed every 24 hours with the same organisms used for growth determination along the larval sub-stage identification. Larval substages were defined according to García (1972). To determine the ratio, we used the Villegas and Kanazawa's (1979) equation:

$$
D I .=\frac{\sum A}{N}
$$

where $A$ is the number of organisms at each sub-stage multiplied by the number assigned to each sub-stage, and $\mathrm{N}$ is the total number of sampled larvae. The absolute number value assigned to each larval sub-stage was: $P Z_{\| I}=3, M_{I}=4, M_{\|}=5, M_{\| I}=6$ and $\mathrm{PL}_{1}=7$.

Percent survival was obtained at the end of the experiment by counting produced postlarvae in the 1-L flasks as, compared to the number of $P Z_{\text {III }}$ placed at the beginning of the experiment.

Extract Preparation. From each sub-stage, 150 larvae were sampled (one hour after being fed) and distributed in three pools each containing 50 organisms. Larvae were washed with distilled water, dried on a $10-\mu \mathrm{m}$ mesh provided with an absorbent paper to extract all the water, and immediately frozen in liquid nitrogen in Ependorff tubes until processing (Palacios 1999). To prepare the extracts, $500 \mu \mathrm{L}$ deionized cold water were added to each tube and the larvae were homogenized over ground ice in a tissue homogenizer for approximately $30 \mathrm{sec}$. Homogenates were centrifuged for $6 \mathrm{~min}$ at $16000 \mathrm{~g}$ at $4 \mathrm{C}$. The supernatant was used to analyze and determine soluble protein, acylglycerides, cholesterol, and digestive enzyme concentrations.

\subsection{Specific Activity of Total Proteases,Ttrypsin and Chymotripsin}

Total proteases activity was measured according to Walter (1984) using azocoll hydrolysis (Sigma A 4341, Sigma Chemical St, Louis, MO, U.S.A.) at 1\%, in a $10 \mathrm{mM}$ phosphate buffer, $\mathrm{pH} 7$, at $37^{\circ} \mathrm{C}$ for $1 \mathrm{~h}$. The reaction was blocked with $5 \%$ trichloroacetic acid (TCA) to precipitate the soluble proteins. After centrifugation, the supernatant was recovered and mixed in equal volumes with a solution of $0.5 \mathrm{M} \mathrm{NaOH}$, and read at $420 \mathrm{~nm}$ in a spectrophotometer (SPECTRONIC model $21 \mathrm{D}$, Spectronic Instruments, U.S.A).

Trypsin activity was measured through hydrolysis of the substrate L-benzoil-arginine-pnitroanilide (BAPNA, $1 \mathrm{mM}$ ), in a $0.1 \mathrm{M}$ TRIS buffer, $\mathrm{pH}$ 8, and read at $405 \mathrm{~nm}$ (Geiger and Fritz, 1988). A unit of trypsin specific activity corresponds to $1 \mu \mathrm{M}$ p-nitroanilide liberated per minute.

Chymotrypsin activity was estimated by the hydrolysis of succinil-alanine-2-prolinephenylalanine $\mathrm{p}$-nitro anilide (SAPPNA, $1 \mathrm{mM}$ ) in a $0.1 \mathrm{M}$ TRIS buffer, $\mathrm{pH} 8$, and read at $405 \mathrm{~nm}$ (Geiger, 1988). A unit of chymotrypsin activity corresponds to $1 \mu \mathrm{M} p$ nitroanilide liberated per minute. 
For all the evaluated enzymes the specific activity was calculated using IU per milligram of protein per dry weight. For this reason, it was considered dry weights obtained from the larvae used for growth determination.

\subsection{Total Soluble Protein}

Total protein was measured by the Bradford method (1976), using the microprotein determination of the Bio-Rad kit (Procedure no. 610) for Elisa microplates. Samples were read after 10 minutes in a microplates Bio-Rad reader (Mod. 550, Bio- Rad, U.S.A) with a $595 \mathrm{~nm}$ filter.

\subsection{Acylglycerides (AG)}

The extract $(10 \mu \mathrm{L})$ was placed on a microplate, adding $200 \mu \mathrm{L}$ of the reactive solution from the Sera-Pak commercial kit Cat. 6684 (50 mM Buffer pH 7; lipoproteinlipase $\geq 50$ $\mathrm{U} / \mathrm{mL}$; glycerokinase $0.055 \mathrm{U} / \mathrm{mL}$; glycerol-phosphate-oxidase $\geq 2.0 \mathrm{U} / \mathrm{mL}$; peroxidase $\geq 3.0 \mathrm{U} / \mathrm{mL} ; 0.7 \mathrm{mM}$ adenosine-5'-triphosphate (ATP); $1.0 \mathrm{mM} \mathrm{4-} \mathrm{aminophenazone;} 7$. $0 \mu \mathrm{M}$ potassium ferrocyanide, $0.6 \mathrm{mM}$ magnesium salts; $1.2 \mathrm{mM}$ N-ethyl-N- (3sulfopropyl)-m-anisine; surfactant $2.0 \mathrm{~g} / \mathrm{L}$ ). The reaction was incubated at room temperature for $10 \mathrm{~min}$ and the absorbance was read at $540 \mathrm{~nm}$. Acylglycerides concentration ( $\mathrm{mg} \mathrm{mL}^{-1}$ ) was calculated from the commercial kit standard.

\section{Cholesterol (CH)}

The extract $(10 \mu \mathrm{L})$ was placed in to the well of the microplates, adding $200 \mu \mathrm{L}$ of reactive solution from the commercial kit Sera-Pak, Cat 6670 (100 mM phosphate buffer, pH 7.2, cholesterol oxidase $\geq 170 \mathrm{U} / \mathrm{L}$; cholesterol ester hydrolase $\geq 400 \mathrm{U} / \mathrm{L}$; peroxidase $\geq 400 \mathrm{U} / \mathrm{L} ; 9 \mathrm{mM} 2$ hydroxyphenylacetic acid; $0.5 \mathrm{mM} 4$ amino-phenasone; $7 \mu \mathrm{M}$ potassium ferrocyanide; tensoactives $6 \mathrm{~g} / \mathrm{L}$ ). Samples were incubated at room temperature for $15 \mathrm{~min}$ and the absorbance was read at $540 \mathrm{~nm}$. Cholesterol concentration $(\mathrm{mg} / \mathrm{mL})$ was calculated based on the commercial kit standard.

\subsection{Statistical Analysis}

To determine whether growth rates, survival, development index and ontogenetic changes in digestive enzymes, lipid and soluble protein reserves were significantly different between the dietary treatments and larval substages, a bifactorial ANOVA and Tukey's multiple comparisons test were used (Zar, 1996). All variables expressed as percent or proportion, were transformed to their arcsine prior to analysis. Value of $P$ was set at the confidence level of 0.05 .

\section{Results}

\subsection{Specific Growth Rate (SGR), Development Index (DI) and Survival}

SGR (PZ III - PL1) obtained by the larvae maintained on treatment BM (7.49 \pm $0.01 \% /$ day) was less than that shown by the larvae fed with LFC $(15.3 \pm 0,039 \%$ / day) (Fig. 1a) $(\mathrm{P}<0.05)$. A value of $10.8 \pm 0.02 \%$ /day was observed for larvae maintained 
with BMK treatment which was not statistically different to larvae maintained on the other treatments (Fig. 1a).

Dietary treatments did not result in differences in survival with ranged from $53 \pm 5 \%$ (BM) to $78 \pm 0.02 \%$ (BMK) (Fig. 1b). Development index (DI) was not significantly different $(p<0.05)$ among the three treatments evaluated, between the 72 and 144 hours (Fig 1c). Only at the beginning (24-48 hours) a significant delay was observed in larvae fed BM or BMK as compared to those fed LFC.

\subsection{Digestive enzymes}

A significant peak of total proteases specific activity was observed in the $M_{\|}$sub-stage, for the larvae fed on BM (355 $\pm 53 \mathrm{mU} / \mathrm{mg}$ protein/ $\mu \mathrm{g} \mathrm{dw}$ ) as compared to the values obtained with BMK (66 $\pm 36 \mathrm{mU} / \mathrm{mg}$ protein $\left.^{\prime} \mu \mathrm{g} \mathrm{dw}\right)$ and LFC (57 $\pm 2 \mathrm{mU} / \mathrm{mg}$ protein $/ \mu \mathrm{g}$ $\mathrm{dw}$ ) treatment (Fig. 2a).

Concerning the ontogenetic changes of total proteases activity, different patterns were observed according to dietary treatment. In larvae fed LFC or BMK, a significant reduction $(P<0.05)$ was observed (Fig. $2 a)$ from $M_{1}$ to $P L_{1}$, whereas for those fed $B M$ a significant reduction $(P<0.05)$ in proteolytic activity, after the peak obtained at $M_{\|}$, was recorded (Fig. 2a).

In regard to trypsin activity, no significant differences were observed among treatments in each sub-stage. For this enzyme, a significant reduction was recorded during development from $M_{1}$ to $P L_{1}$ only in larvae fed on the LFC and BMK treatment (Fig. 2b).

A significant reduction in chymotrypsin activity (85\%) from ontogenetic origin was obtained in larvae fed LFC from $M_{1}$ to $\mathrm{PL}_{1}(P<0.05)$. In relation to larvae fed $B M K$ treatment no significant reduction of the activity was observed. Statistical comparison of chymotrypsin specific activity in each larval sub-stage showed that, only during $M_{\|}$ was significantly higher level recorded in larvae fed BM (Fig. 2c).

\subsection{Biochemical composition of larval stages}

The highest soluble protein content $(P)$ values were obtained for larvae fed on LFC with significant differences $(P<0.05)$ observed in PL1 $(32 \pm 0.4 \% / d w)$ as compared to shrimp fed on artificial diets (Fig. 3a). Acylglycerides content (AG), did not show any differences whatever dietary treatments. However, ontogeny development indicated a significant increment at $M_{I I I}$ fed LFC compared to $M_{1}$ fed BM (Fig. 3b). The cholesterol content $(\mathrm{CH})$ evaluated in $\underline{L}$. vannamei mysis did not show significant fluctuations during all sub-stages with any of the dietary treatments, except a peak to $M_{\text {III }}$ with LFC treatment (Fig. 3c).

The acylglycerides:protein ratio $(A G / P)$ diminished along the larval development with each dietary treatment; with a significant decreased observed only during $\mathrm{PL}_{1}$ with LFC (Fig. 3d). The acylglycerides:cholesterol ratio (AG/CH) revealed a stable evolution along the mysis sub-stages and at $\mathrm{PL}_{1}$. However, in larvae fed on the BMK diet, a significantly increased in $\mathrm{M}_{\mathrm{II}}$ was observed (Fig. 3e).

The cholesterol:protein ratio $(\mathrm{CH} / \mathrm{P})$ tended to decrease during larval development similarly to the AG:P ratio. The effect of dietary treatment on this ratio was significant in $M_{l}$ and $M_{\| l}$, reaching significantly higher values with the LFC and BM treatments respectively (Fig. 3f). A low $\mathrm{CH} / \mathrm{P}$ ratio was observed in $\mathrm{PL} 1$ for all treatments $(\mathrm{P}<0.05)$ 


\section{Discussion}

The use of krill hydrolysate in the feed has been reported to affect a number of digestive enzymes. The secretagogue effect of krill hydrolysate included in the microencapsulated (BMK) diet was not evident through the total proteinases, trypsin, and chymotrypsin specific activities when compared to the BM and LFC. Furthermore, the BM diet, which did not contain krill hydrolysate, induced a peak of activity for total proteinases and chymotrypsin enzymes during $\mathrm{M}_{\|}$as compared to both BMK and LFC treatments. BM diet contained native squid, which had been substituted with krill hydrolysate in BMK. Le Moullac et al. (1994) reported that squid produced the highest chymotrypsin activity in L. vannamei larvae. However, growth and survival were not positively affected by BM as with the BMK treatment compared to control (LFC). The ontogenetic reduction of enzymatic activities was confirmed, derived from the ontogenetic changes of the digestive tube of shrimp larvae, as reported for other penaeid shrimp species by Lovett and Felder (1990a), Le Vay et al. (2001), Anger (2001) and Lemos and Phan (2001). This ontogenetic change is related to the disappearance of the anterior caeca observed in mysis sub-stages of $\underline{L}$. setiferus by Lovett and Felder (1989) and by Abubakr and Jones (1992) in Penaeus monodon. These changes are associated with a variation in feeding habits of omnivorous crustacean larvae. An increase in trypsin content during herbivorous sub-stages of protozoea, reached a peak in the transition to mysis, and declined afterwards, during the carnivorous phase, in the stages of mysis and first postlarvae as shown before (Laubier-Bonichón et al., 1977; Lovet and Felder, 1990b; Le Vay et al., 1993; Jones et al., 1993; and Le Vay et al. 2001).

In other studies, the use of probiotics in the rearing water of larval $\underline{L}$. vannamei, promoted survival to PL1 and increased digestive activity but only in the early postlarvae (PL1-PL8) stages (Zhou et al., 2009). As stated by Le Vay et al. (2001), in herbivorous and omnivorous shrimp larvae and under laboratory conditions with high feed available, ingestion rates tended to be high and are accompanied by a high exchange rate in the digestive tract (Kurmaly et al. 1989; Lovett and Felder 1990b); therefore, as a strategy, a high enzymatic activity allowed larvae to extract most of the digestible compounds, retrieve nutritional entities with a relatively low assimilation efficiency and gain more net energy (Le Vay et al., 2001). In the present study proteinases activity, as an indicator of digestive activity of shrimp larvae showed that the secretagogue effect of krill hydrolysate only was evident during Mysis I stage, indicating that MBK and LFC diets had an important role into the digestive stimulation, just when shrimp larvae requires a change in digestive capacity due to raptorial behavior. Total proteinases and chymotrypsin activities showed no differences between mysis sub-stages and PL1 stage fed all diets showing a stable behavior in activity during this 3-4 days period. The digestive enzymes activity is very similar in L. vannamei mysis larvae fed with either BMK or LFC, and indicate the wide flexibility of the digestive system of larvae at this stage, where the digestive enzymes to be active received equivalent substrates (A. franciscana nauplii or microcapsules).

Weight gain is a direct response of the diet effect and summarizes the physiological, biochemical, and nutritional adaptations (in terms of requirements) of organisms. In this study, the high percentage of survival, specific growth rate, and development obtained with BMK treatment was close to those obtained with LFC, suggesting that the artificial diet was well consumed and covered the nutritional requirements of shrimp larvae. Specific growth rate was significantly lower when fed BM indicating that in this diet there are some missing nutrients that affected larval performance. This could be related to the diet's composition with the squid that in spite of its stimulant role in digestive activity (analyzed though differences found in each substage) could produce 
a poor assimilation of the diet, with consequences into biomass accumulation and survival.

The decapod larvae are composed of proteins (>30\%), lipids (>20\%), chitin $(>15 \%)$ and free carbohydrates $(<5 \%)$. One aspects of crustacean larval nutrition is the effect of diet on larval biochemical composition, leading to modification in the pattern of developmental growth (Anger, 2001). In larvae of decapod crustacean, triacylglycerides, phospholipids, and free sterols compose the predominant lipid fractions (Anger, 2001). Among these, triacylglycerides (TAG) constitute the main source of energy reserve (Sasaki et al., 1986; Galois, 1987; Chandumpai et al., 1991; Dall et al., 1992, Mourente et al., 1995). Teshima and Kanazawa (1982) also reported the presence of mono- and di-acylglycerides in the different larval stages of Marsupenaeus japonicus. The technique to evaluate the total quantity of acylglycerides in $L$. vannamei included all acylglycerides representing lipid reserves. Nutrient intake provided by BM, BMK, and LFC maintained similar acylglycerides reserves during the mysis stage, indicating that both microcapsules and A. franciscana nauplii presented a similar lipid quality, which later on could be assessed through the absence of significant differences in larval development (Fig 1c). Quality lipids will contribute to success in efficient development of shrimp larvae as well as adequate use of energy reserves (Mourente et al., 1995). A lower acylglycerides content in larvae fed with BM as compared to that of larvae fed on BMK and LFC treatments was observed at $\mathrm{PL}_{1}$ stage only suggesting that some lipids could be missing into the BM diet affecting larval growth and survival.

Cholesterol is an ecdysteroid hormone precursor (Lehninger, 1993), which can not be synthesized by crustaceans (Teshima and Kanazawa, 1982). It is a stable structural compound due to its participation in cell membranes structure, independently of feeding conditions (Fraser, 1989; Anger, 2001). This pattern of stability of the values from the three dietary treatments though all the larval substages was confirmed (Fig. 1i).

In terms of lipid reserves the ratio of tricylglycerides:cholesterol has been proposed as a reference for larvae condition. This ratio was modified to a acylglycerides:cholesterol $(\mathrm{AG} / \mathrm{CH})$ ratio in the present study. Although acylglyceride reserves did not show significant differences during mysis stage and $\mathrm{PL}_{1}$ among dietary treatments (except a lower value in larvae fed $B M$ in $\mathrm{PL}_{1}$ ), a decrease of lipid reserves in animals fed with LFC during $M_{1}$ was observed, whereas BM and BMK treatment maintained a more constant lipid reserves supply (Fig 3a). However, these variations did not effects larval survival and development (Fig. 1b and 1c). This does not mean that variation does not exist. Simply, at the level of sampling it was not possible to detect a variation. Such variation in cholesterol is known in relation with molting in crabs and the lipocytic coefficient increases as a physiological response for water absorption at tissue level to trigger exuviation. On the other hand and with regard to the AG/protein ratio, which can be used as a parameter for energetic condition of crustaceans larvae (Anger, 2001), the significant decrease observed at mysis sub-stages according to dietary treatments, indicates that lipid reserves were maintained constant (Fig 3d). The exponential increase in protein content produced an exponential decrease of AG/protein ratio values, evidencing that, at mysis stage, an exponential growth rate is common. The ratio cholesterol:protein $(\mathrm{CH} / \mathrm{P})$ can be used as an indicator of an increase in biomass structure (Anger, 2001). Accordingly, the pattern observed in this research contrasts with those remaining constant in Homarus americanus during the larval phase (Sasaki, 1986).

Larval growth, survival and development are often used in diet evaluation for shrimp (Kanazawa, 1985; Jones et al., 1993; Cahu and Zambonino, 1997) and integrate 
directly the effects of food type supplied on shrimp larvae (Jones et al., 1997). Similar responses evidenced that $\underline{A}$. franciscana nauplii commonly used in feeding mysis larvae can be substituted with the microencapsulated diet containing krill hydrolysate.

\section{Conclusion}

Replacement of Artemia franciscana by inert dry particles is going to be more and more efficient with progress in formulation, increase in palatability, number of meals per day and optimum rearing conditions $\left(\mathrm{T}^{\circ} \mathrm{C}\right.$, aeration, light) and a constant survey of the larvae during critical phases before metamorphosis.

\section{Acknowledgments}

We thank UNAM IN 234596 and IN- 220505 and CONACYT 38193 for financial support. To CONACyT for the graduate (Ph.D) studies grant to MS. Pedro Pablo Gallardo. Also to Ingrid Mascher for language assistance.

\section{Literature cited}

Abubakr B., Jones D. A., 1992, Functional morphology and ultrastructure of the anterior midgut diverticula of Penaeus monodon (Fabricius, 1789) larvae. Crustaceana, 62 (2): $142-158$.

Aldman G., Jonson A. C., Jensen J. Holmgren S., 1989. Gastrin/CCK - like peptides in the spine dogfish, Squalus acanthias: concentrations and actions in the gut. Comparative Biochemistry and Physiology, 92C (1):103 - 108.

Anger K., 2001. The biology of decapod crustacean larvae In: R. Vonk (ed). Crustacean Issues, AA Balkema Publishers, Amsterdan Netherlands, Vol 14, 407 pp.

A.O.A.C., 1990. Official Methods of Analysis, 13 ed. USA, Washington D.C.

Bradford M. M., 1976. A rapid and sensitive method for the quantification of microgram quantities of protein utilizing the principle of protein dye binding. Annals of Biochemistry, 72: 248-254.

Cahu C.L. and Zambonino Infante J.L., 1994. Early weaning of sea bass (Dicentrarchus labrax larvae with a compound diet: effect on digestive enzymes. Comparative Biochemistry and Physiology, 109, 213-222.

Cahu C.L. and Zambonino Infante J.L., 1997. Is the digestive capacity of marine fish larvae sufficient for compound diet feeding?. Aquaculture International, 5: 151-160. 
Cahu C.L., Zambonino Infante, J.L. Quazuguel, and Le Gall M.M., 1999. Protein hydrolysate vs. fish meal in compound diets for 10 day old sea bass Dicentrarchus labrax larvae. Aquaculture 171: 109-119.

Carvahlo A.P., Escaffe A.M. Oliva Teles A., Bergot P., and Kaushik S., 1998. First feeding of common carp larvae on diets with high levels of protein hydrolysates. Aquaculture International 5: 361-367.

Chandumpai A., Dall W., and Smith, D.M., 1991. Lipid class composition of organs and tissues of the tiger prawn Penaeus esculentus during the moulting cycle and during starvation. Marine Biology, 108: 235-245.

Cordova-Murueta J.H., and Garcia-Carreño F.L., 2002. Nutritive value of squid and hydrolyzed protein supplement in shrimp feed, Aquaculture, 210: 371-384.

Cuzon, G. and Guillaume, J. 1997. Energy and Protein:Energy Ratio p 51-70. In: D'Abramo, L.R., Conklin, D.E., and Akiyama, D. M. Crustacean Nutrition, Advances in World Aquaculture Vol, 6, World Aquaculture Society, Baton Rouge, Lousiana, U.S.A.

Dall W., Chandumpai A., and Smith D.M., 1992. Fatty acid composition of organs and tissues of the tiger prawn Penaeus esculentus during moulting cycle and during starvation. Marine Biology, 113 (1): 45-55.

Fraser A., 1989. Triacylglycerol content as a condition index for fish, bivalve and crustacean larvae. Canaidian Journal of Fisheries Aquatic Sciences, 46: 1868-1873.

Gallardo P. P., Alfonso E., Gaxiola G., Soto L. A., and Rosas C., 1995. Feeding schedule for Penaeus setiferus larvae based on diatoms (Chaetoceros ceratosporum),

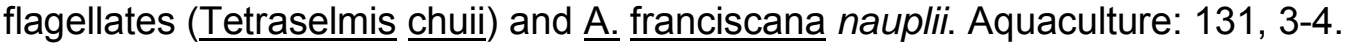

Gallardo P.P., Pedroza-Islas R., Garcia-Galano T., Pascual C. Rosas C., Sanchez A. and Gaxiola G., 2002. Replacement of live food with a microbound diet in feeding Litopenaeus setiferus (Burkenroad) larvae. Aquaculture Research, 33(9) : 681-691.

Galois R., 1987. Les lipides neutres chez les Crustacés Decapodes: métabolisme et besoins. Oceanis, 13: 197-215.

García T., 1972. Descripción de los estadios larvales del camarón blanco, Penaeus schmitti Burkenroad, obtenidos en el laboratorio. Centro de Investigaciones Marinas, Universidad de la Habana, Cuba. Serie Investigaciones Mar. 1: 1-54.

Geiger R., 1988. Chymotrypsin In: Bergmeyer J., Grab, BmM. (Eds), Methods of enzymatic analysis, Enzymes 3: Peptidases, proteinases and their inhibitors Verlag Chemie, Einheim, Vol 5, 3rd edition: 99-104.

Geiger R. and Fritz H., 1988. Trypsin. In: Bergmeyer J., Grab, BmM. (Eds), Methods of enzymatic analysis, Enzymes 3: Peptidases, proteinases and their inhibitors Verlag Chemie, Einheim, Vol 5, 3rd edition:119-124.

Jones D.A., Kamarudin M. S., and Le Vay L., 1993. The potential for replacement of live feeds in larval culture. Journal of the World Aquaculture Society, 24 (2): 199-210.

Jones D.A., Yule A.B., and Holland D.L., 1997. Larval nutrition, In: D’Abramo L., Conklin D.E., and Akiyama D.M. (Eds) Crustacean Nutrition. Advances in World Aquaculture, World Aquaculture Society, Baton Rouge, LA, USA. Vol 6: 353-389. 
Johnson L. R. E., Copeland E. M., and Dudricks S. J., 1978. Luminal gastrin stimulates growth of the distal intestine. Scand. Journal of Gastroenterology, 13 (49) 95 p.

Kanazawa A., 1985. Microparticulated diets. In: Yone Y. (Ed.) Fish nutrition and diets, , Koseisha-Koseikaku, Tokyo. p 99-110.

Kolkowski S., Czesny S., and Dabrowski K., 2000, Use of krill hydrolysate as a feed attractant for fish larvae and juveniles. Journal of the World Aquaculture Society, 31(1): $81-88$.

Kumlu M., and Jones D.A., 1997. Digestive protease activity in planktonic crustaceans feeding at different trophic levels. Journal Mariculture Biology, Association, U.K. 77 (1): 159-165.

Kurmaly K., Jones D.A., Yule A.B., and East J., 1989. Comparative analysis of the growth and survival of Penaeus monodon (Fabricius) larvae, from protozoea I to postlarva 1 on live feeds, artificial diets or combination of both. Aquaculture, $81: 27-45$.

Laubier-Bonichon A., Van Wormhoudt A., and Sellos D., 1977. Croissance larvaire contrôlée de Penaeus japonicus Bate: enzymes digestives et changements de régimes alimentaires. Publication Centre. Naturel Exploitation, Oceans: Actes Colloques, 4 : 131145.

Lehninger A.L., Nelson D.L., Cox M.M., 1993. Principles of biochemistry, 2nd ed. Worth Publishers, New York, NY, USA.

Le Moullac G., and Van Wormhoudt A., AQUACOP, 1994. Adaptation of digestive enzyme to dietary protein carbohydrate and fiber levels and influence of protein and carbohydrate quality in Penaeus vannamei larvae (Crustacea:decapoda). Aquatic Living Resources, 7: 203-210.

Lemos D. and Phan V.N., 2001. Ontogenetic variation in metabolism, biochemical composition and energy content during the early life stages of Farfantepenaeus paulensis (Crustacea: Decapoda: Penaeidae). Marine Biology, 138: 985-997.

Le Vay L., Rodríguez A., Kamarudin M.S., and Jones D.A., 1993. Influence of live and artificial diets on tissue composition and digestive enzyme activity in Penaeus japonicus larvae. Aquaculture, 118: 287-297.

Le Vay L. Jones D.A., Puello -Cruz A., Sangha R.S., and Ngamphonsai C., 2001. Digestion in relation to feeding strategies exhibited by crustacean larvae. Comparative Biochemistry and Physiology Part A 128: 623-630.

Lovett D.L., and Felder D.L., 1989. Ontogeny of gut morphology in the white shrimp Penaeus setiferus (Decapoda; Penaeidae). Journal of Morphology_ 201: 253-272.

Lovett D. L., Felder D. L., 1990a. Ontogenetic change in digestive enzyme activity of larval and postlarval white shrimp Penaeus setiferus (Crustacea, Decapoda, Penaeidae). Biological Bulletin, 178: 144-159.

Lovett D. L., and Felder D.L., 1990b. Ontogeny of kinematics in the gut of the white shrimp Penaeus setiferus (decapoda:Penaeidae). Journal of Crustacean Biology, 10: 53-68. 
Mourente G., Medina A., González S., and Rodríguez A., 1995. Variations in lipid content and nutritional status during larval development of the marine shrimp Penaeus kerathurus. Aquaculture 130: 187-199.

Nicol S. and Endo. Y., 1997. Krill fisheries of the world. FAO Technical paper: No. 367, Rome, Italy. p 100

Palacios Metchenov E., 1999. Caracterización fisiológica del agotamiento reproductivo y optimización de la reproducción del camarón blanco del pacifico Penaeus vannamei (Boone, 1931) (Decapoda:Penaeidae). Ph.D dissertation. Centro de Investigaciones Biológicas del Noroeste, S.C. Mexico. ,193 pp

Pedroza-Islas R, Vernon-Carter E.J., Durán-Dominguez C., and Trejo - Marínez S., 1999. Using biopolymer blends for shrimp feedstuff microencapsulation. I. Particle size, morphology and microstructure of microcapsules. Food Resources International, 32: 367-374.

Pedroza-Islas R, Vernon-Carter E.J., Durán-Dominguez C., and Trejo-Marínez S., 2000. Using biopolymer blends for shrimp feedstuff microencapsulation. II. Dissolution and flotability kinetics as selection criteria. Food Resources International, 33: 119-124.

Pedroza-Islas R., Gallardo P., Vernon-Carter E.J., García-Galano, T. Rosas C. Pascual C. \& Gaxiola G. 2004. Growth, survival, quality, and digestive enzymes activities of larval shrimp fed microencapsulated, mixed, and live diets. Aquaculture Nutrition. Vol. 10 (3): $167-173$.

Ravallec-Plé R., 2000. Valorisation d'hydrolysats d'origine marine: optimisation de la concentration en peptides apparentés aux facteurs de croissance et aux agents secrétagogues. Essais in vitro et in vivo. Ph.D dissertation,. Université de Bretagne Occidentale, France. $206 \mathrm{p}$

Reifel C.W., Mainr-Sorensen M., and Samloff M., 1983. Gastrin immunoreactive cells in the gastrointestinal tracts from four species of fish. Canaidian Journal of Zoology, 61: 1464-1468.

Reinecke M., Drakemberg K., Falkmenr S., and Sara V.R., 1992. Peptides related to insulin-like growth factor 1 in the gastro-entero-pancreatic system of bony and cartilaginous fish. Reg. Pep. 37 : 155-165.

Sarvi B., Matinfar A., Mahmoudzadeh H., and Reza G., 2010. Replacing rotifer with a microparticle diet from first feeding in yellowfin seabram, Acanthopagrus latus (Houttuyn), larvae. Aquaculture research, 41: 1614-1621.

Sasaki G.C., Capuzzo J.M., and Biesiot P., 1986. Nutritional and bioenergetic considerations in the development of the American lobster Homarus americanus Milne Edwards, Can J. Fish. Aquaculture Science, 43: 2311-2319.

Storebakken T., 1988. Krill as a potential feed source for salmonids. Aquaculture, 70: 193-205.

Teshima S., and Kanazawa A., 1982. Variation in lipid composition during the larval development of the prawn Penaeus japonicus. Memories Faculty of Fish Kagoshima University 31: 205-212. 
Treece G. D., and Yates .M.E., 1990. Laboratory manual for the culture of penaeid shrimp. Marine Advisory Service Sea Grant College Program Texas A\&M University, College Station. . TAMU-SG-88-202 (R) USA. 95 pp

Van Wormhoudt A., and Dircksen H., 1990. Gastrin/CCK-like peptides in the nervous system and the stomach of crustaceans. Frontiers In crustacean neurobiology. Advances in life sciences. . Birkhauser Verlag, Basel, Switzerland. $483 \mathrm{pp}$

Villegas D. K., and Kanazawa A., 1979 Relationship between diet composition and growth of the zoeal and mysis stages of Penaeus japonicus Bate. Fisheries Research Journal, 4(2): 32-40.

Walter H.E., 1984. Proteinase methods with hemoglobin, casein and azocoll as substrates. In: Bergmeyer J., Grab M. (Eds.) Methods in Enzymatic Analysis V,. Verlag Chemie, Weintheim. p.270-277

Zar J.H., 1996. Biostatistical Analysis,. Prentice Hall, New York, USA . 620 pp

Zhou X, Wang Y, and Li W. 2009. Effect of probiotic on larvae shrimp (Penaeus vannamei) based on water quality, survival rate and digestive enzyme activities. Aquaculture. Vol. 287. P. 349-353. 
Tables

TABLE 1.- Ingredient composition $(\mathrm{g} / \mathrm{kg})$ of the microparticulate diets for the microcapsules used in the experiment. The proportion of agent's encapsulants: microparticulates diets were 2: 1 .

\begin{tabular}{|c|c|c|}
\hline Ingredients & BM & BMK \\
\hline Fish muscle (Scomberomorus sierra) & 270 & 270 \\
\hline Squid mantle muscle & 170 & \\
\hline Krill hydrolysate* & & 170 \\
\hline Shrimp muscle (Litopenaeus setiferus) & 170 & 170 \\
\hline Saccaromices cereviseae & 150 & 150 \\
\hline Soybean meal & 140 & 140 \\
\hline Wheat starch & 15 & 15 \\
\hline Cod liver oil & 20 & 20 \\
\hline Sunflower oil & 20 & 20 \\
\hline Soybean lecithin & 10 & 10 \\
\hline Cholesterol & 5 & 5 \\
\hline Vitamin and mineral premix ${ }^{* *}$ & 25 & 25 \\
\hline Stay $C^{* * *}$ & 5 & 5 \\
\hline \multicolumn{3}{|c|}{ Proximate composition of microcapsules $(\mathrm{g} / \mathrm{kg})^{1}$} \\
\hline Moisture & 47 & 53 \\
\hline Crude protein & 177 & 172 \\
\hline Total lipids & 33 & 31 \\
\hline Ash & 61 & 67 \\
\hline Nitrogen free extract & 681 & 687 \\
\hline Digestible energy $(\mathrm{MJ} / \mathrm{kg})^{2}$ & 17.3 & 17.3 \\
\hline
\end{tabular}

* Krill hydrolysate under liquid form (Specialty Marine Products).

** Agribrands Purina de México property information only vitamin types are given; A $\mathrm{UI} / \mathrm{kg}$; D; E; K; Beta-caroten; thiamin; pyridoxine; riboflavin; cyanocobalamin; ac.folique; nicotinamid; panthotenic; biotine; C; carophyll red; choline; inositol.

${ }^{* * *}$ Roche.

1 Moisture, protein, lipids, and ash contents were determined following methods established by A.O.A.C. (1990) (protocols 934.01, 976.05, 920.39 and 942.05, respectively).

${ }^{2}$ Estimated from Cuzon \& Guillaume (1997) on the basis of energy content estimates of $21.3,17.6$, and $39.5 \mathrm{~kJ} \mathrm{~g}^{-1}$ for proteins, carbohydrates, and lipids, respectively. 


\section{Figures}

FIG.1. (a) Specific growth rate (\%/day), (b) survival (\%) and (c) development index (ID) of Litopenaeus vannamei larvae fed microencapsulated diets (BM and BMK) and live food (microalgae and artemia nauplii). Means $\pm S$.E. $N=3$ repetitions. Different letters indicate significant differences between sub-stages; different symbols $\left({ }^{*},+\right)$ indicate significant differences among treatments in each sub-stage. $\mathrm{T}=$ treatments, $\mathrm{S}=$ Substage and N.S. = Not significant.
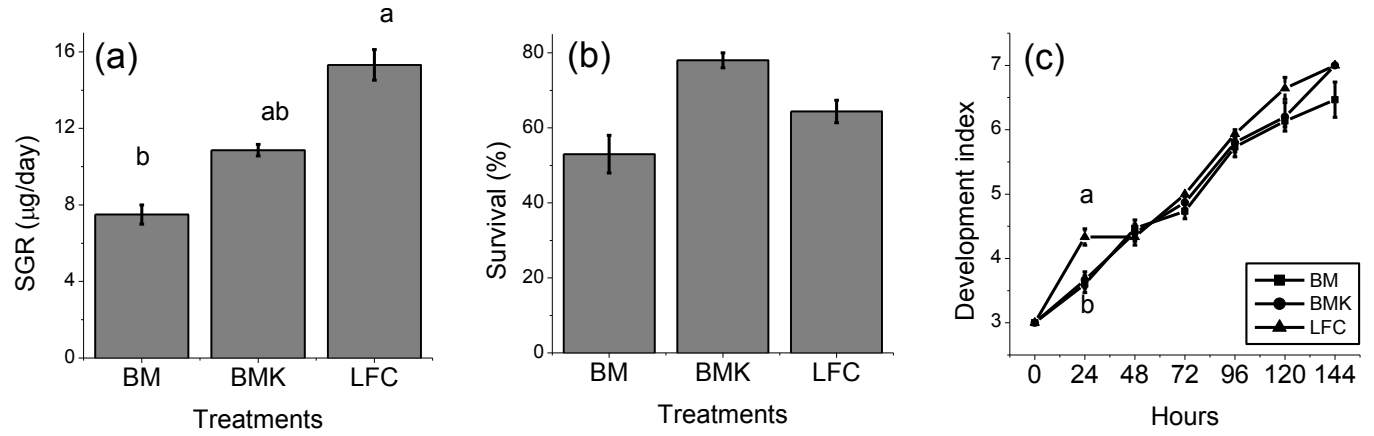

Fig. 2. Specific activity of (a) total proteases, (b) trypsin and (d) chymotrypsin (UI mg protein/g dw) of Litopenaeus vannamei larvae fed microencapsulated diets (BM and $B M K)$ and live food (microalgae and artemia nauplii). Means \pm S.E. $N=3$ repetitions. Different letters indicate significant differences between sub-stages; different symbols $\left({ }^{*},+\right)$ indicate significant differences among treatments in each sub-stage. $\mathrm{T}=$ treatments, $\mathrm{S}=$ Substage and N.S. = Not significant.
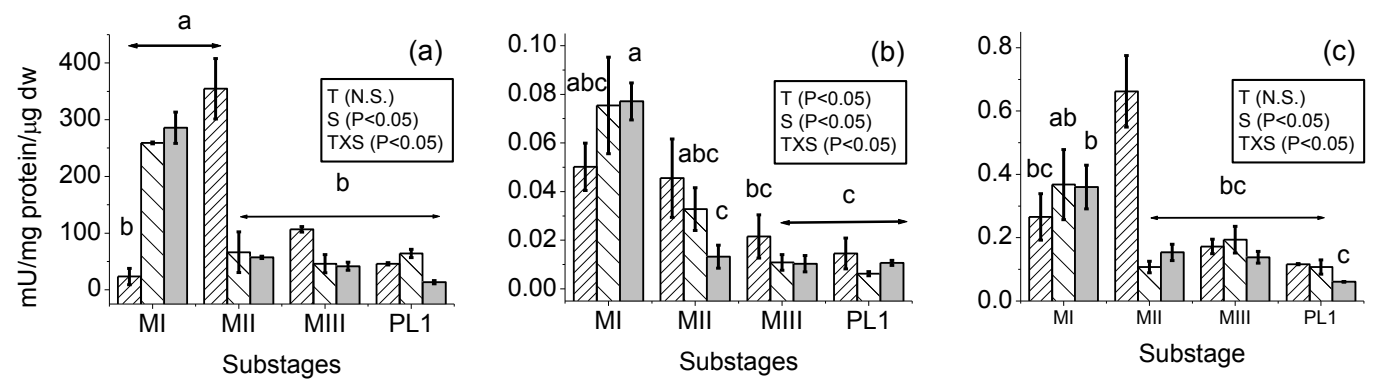
Fig. 3. (a) Total protein, (b) acylglycerides (AG), (c) cholesterol content (\%/dw) and (d) AG/cholesterol, (e) AG/protein and (f) cholesterol/protein ratios of Litopenaeus vannamei larvae fed microencapsulated diets (BM and BMK) and live food (microalgae and artemia nauplii). Means $\pm \mathrm{S}$.E. $\mathrm{N}=3$ repetitions. Different letters indicate significant differences between sub-stages; different symbols $\left({ }^{*},+\right)$ indicate significant differences among treatments in each sub-stage. $T=$ treatments, $S=$ Substage and N.S. $=$ Not significant.
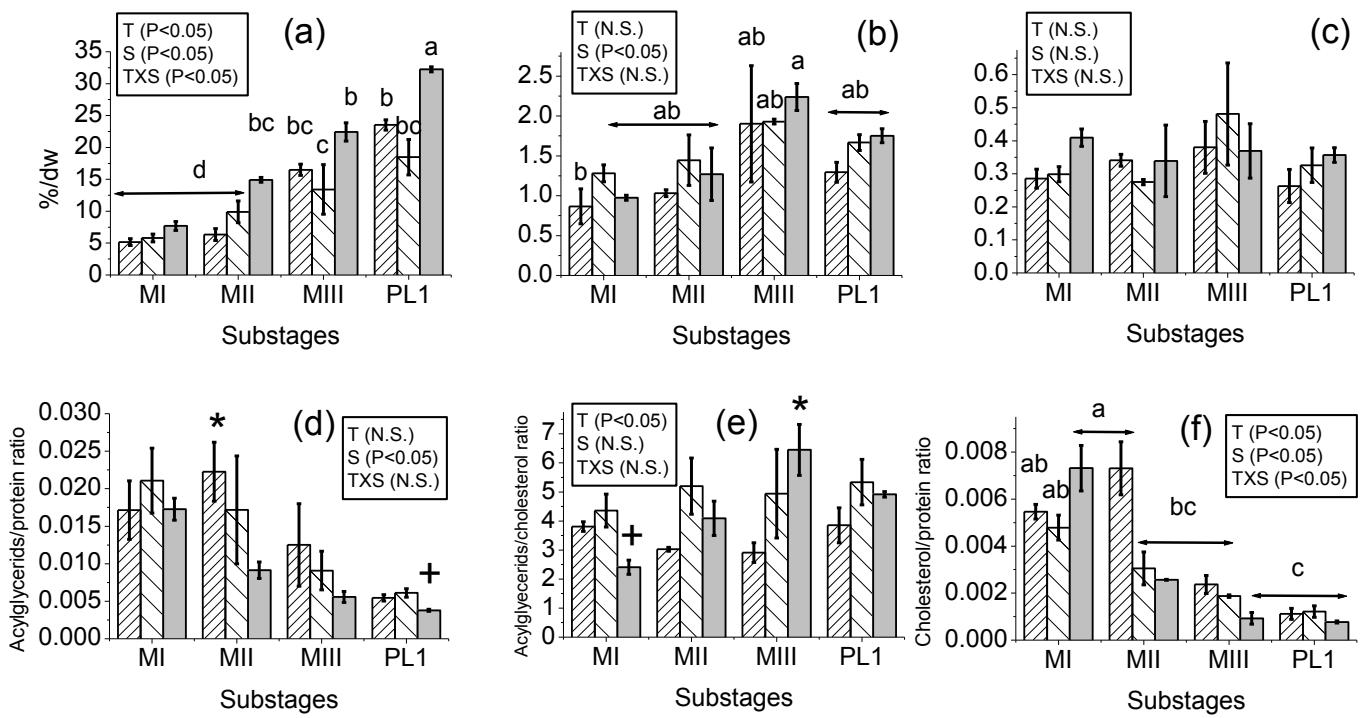

$\square \mathrm{BM} \square \mathrm{BMK} \square \mathrm{LFC}$ 